\title{
Pentoxifylline and Other Protein Kinase C Inhibitors Down-Regulate HIV-LTR NF- $\kappa B$ Induced Gene Expression
}

\author{
Debajit K. Biswas, ${ }^{*}$ Christoph M. Ahlers, ${ }^{\dagger}$ Bruce J. Dezube, ${ }^{\dagger}$ \\ and Arthur B. Pardee ${ }^{\dagger}$ \\ *Division of Cell Growth and Regulation, Dana-Farber Cancer \\ Institute, Boston, Massachusetts, U.S.A. \\ ${ }^{\dagger}$ Harvard Medical School, Boston, Massachusetts, U.S.A.
}

\begin{abstract}
Background: This investigation deals with the molecular mechanism of anti-human immunodeficiency virus type 1 (HIV-1) action of pentoxifylline (PTX) [1-(5'-oxohexyl)-3,7-dimethylxanthine] a drug widely used for the treatment of conditions involving defective regional microcirculation.

Materials and Methods: The inhibition by PTX of protein kinase $\mathrm{C}$ (PKC) or cAMP-dependent protein kinase (PKA)-mediated activation by phorbol ester (PMA) and tumor necrosis factor alpha (TNF- $\alpha$ ) of HIV-1-LTR-regulated reporter gene expression was studied in human $\mathrm{CD}^{+}{ }^{+} \mathrm{T}$ lymphocytes (Jurkat) and human embryo kidney cells (293-27-2). A protein kinase $C$ is involved in activation of NF- $\kappa$ B in whole cells, identified by using inhibitors specific for PKC- or PKA-catalyzed NF- $\kappa$ B activation in whole cell and cellfree systems.

Results: PTX inhibited PKC- or PKA-catalyzed activa-
\end{abstract}

tion of NF- $\kappa$ B in cytoplasmic extracts from unstimulated Jurkat or 293-27-2 cells, but not interaction of preactivated NF- $\kappa \mathrm{B}$ with its motifs. Calphostin $\mathrm{C}$, a specific inhibitor of PKC, inhibited NF- $\kappa$ B activation and HIV-1 LTR-driven reporter gene expression in both PMA- and TNF- $\alpha$-treated cells. In contrast, although H88 specifically inhibited PKA activity in the cell-free extract, it did not affect NF- $\kappa$ B action in PMAor TNF- $\alpha$-treated cells.

Conclusions: The mechanism of inhibitory action of PTX on virus replication and NF- $\kappa \mathrm{B}$-induced transactivation of HIV-l gene expression has been elucidated as due to blocking PKC-dependent PMA- or TNF- $\alpha$-induced activation of NF- $\kappa$ B in Jurkat and 29327-2 cells. Other protein kinase inhibitors may be useful in down regulating transcription of HIV-1 provirus and thereby virus replication in HIV-infected patients.

\section{INTRODUCTION}

Human immunodeficiency virus type 1 (HIV-1) is implicated in the deadly disease acquired immune deficiency syndrome (AIDS). Identification and characterization of agents that block its replication are currently being investigated intensively. Provirus transcription is regulated by interactions of several cellular and viral transacting proteins, including NF- $\kappa \mathrm{B}$, with specific sequences in the long terminal repeat (LTR) of HIV-1 (1). We have reported that treatment of

Address correspondence and reprint requests to:

Debajit K. Biswas, Division of Cell Growth and Regulation, Dana-Farber Cancer Institute, Dana-810, 44 Binney Street, Boston, MA 02115, U.S.A. cells with pentoxifylline (PTX) [1-(5-oxohexyl)3,7-dimethylxanthine] inhibits HIV-1 replication (2). PTX is also widely used for the treatment of different human peripheral blood disorders. The drug down-regulates HIV-1 LTR-driven gene expression in stimulated cells through its action upon the two nuclear factor kappa B (NF- $\kappa$ B) motifs in the LTR (3). The antiviral action of PTX may be due to inhibition of any one or more of at least six steps of trans-activation by NF- $\kappa \mathrm{B}$ in whole cells: (1) activation of a protein kinase; (2) activation of NF- $\kappa$ B by kinase action upon the inactive cytoplasmic NF- $\kappa \mathrm{B}-\mathrm{I} \kappa \mathrm{B}$ complex; (3) $\mathrm{NF}-\kappa \mathrm{B}$ release from phosphorylated $\mathrm{I} \kappa \mathrm{B} ;(4)$ translocation of NF- $\kappa \mathrm{B}$ into the nucleus; (5) its 
interaction with the two NF- $\kappa \mathrm{B}$ motifs in the HIV-1 LTR; and (6) bound NF- $\kappa$ B stimulation of promoter function, the end result of these steps.

$\mathrm{NF}-\kappa \mathrm{B}$ is present in most cells as an inactive complex that is activated by diverse agents such as cytokines TNF- $\alpha$ and interleukin-1 (IL-1) $(4,5)$, phorbol ester (PMA), cAMP, protein synthesis inhibitors, lipopolysaccharides, deoxycholate, and formamide (6-9). NF- $\kappa \mathrm{B}$ is also activated by double-stranded RNA (10) and the HTLV protein tax-l (11). Activation of NF- $\kappa B$ is dependent on the phosphorylation of $\mathrm{I} \kappa \mathrm{B}$, an inhibitor complexed to NF- $\kappa \mathrm{B}$ in the cytoplasm $(7,12-14)$. The reaction is catalyzed by various protein kinases in different cell types (15). Mitogen-like phorbol ester (PMA)-induced activation is mediated by protein kinase $C$ (PKC), as is induction by some cytokines such as TNF- $\alpha$ (1619). Meichle et al. (20) suggested a PKC-independent physiological activation of NF- $\kappa \mathrm{B}$, and cell-specific differences in PKC-dependent activation of NF- $\kappa \mathrm{B}$ are reported (21). IL-1-induced activation of NF- $\kappa \mathrm{B}$ in certain cells was mediated by cAMP-dependent protein kinase A (PKA) $(9,22)$. The involvement of Raf-1 kinase in the activation of NF- $\kappa$ B was also reported (23).

The inhibitors of protein kinases used in most of the above studies have overlapping actions on both PKC and PKA. Contradictory results were obtained with the frequently used inhibitors H7 [1-(5-isoquinoline-sulfonyl)-2methylpipirazine hydrochloride] (24-28), H8 (29), and staurosporine (20). Effects of $\mathrm{H} 7$ were also dependent on the commercial source (30). H7 may be a mixture of two isomers; some preparations have a higher concentration of one or the other (31). Other protein kinase inhibitors were recently described that have more specific and selective inhibitory activity against PKA and PKC. Calphostin C, a secondary metabolite of the fungus Cladosporium cladosporioides, is a selective inhibitor of PKC with a reported IC 50 of $0.05 \mu \mathrm{M}$, whereas the $\mathrm{IC}_{50}$ of this drug for PKA is about 50 $\mu M(32,33)$. Calphostin $C$ inhibits protein kinase $\mathrm{C}$ by competing for the binding site of diacylglycerol and PMA, and its action is light-dependent (34). Qatsha et al. (35) reported that Gö 6976, a nonglycosidic indolocarbazole and a selective inhibitor of PKC ( $\mathrm{IC}_{50} 0.02 \mu \mathrm{M}$ ) is an antagonist of HIV-1 induction from latent/lowlevel-producing reservoir cells in vivo. Chelerythrine is another newly identified selective PKC inhibitor (36). Its IC so $_{50}$ for PKC is $0.66 \mu \mathrm{M}$ and $\mathrm{IC}_{50}$ for PKA is $170 \mu \mathrm{M}$. In contrast, H88 [N- (2 - cinnamylaminoethyl) - 5 - isoquinolinesul- fonamide], a derivative of $\mathrm{H} 89$ (37), is a selective inhibitor of PKA with $\mathrm{IC}_{50}$ of $0.36 \mu \mathrm{M}$ whereas $\mathrm{IC}_{50}$ of this drug for PKC is $75 \mu \mathrm{M}$.

In this investigation we have attempted to identify the site or sites of PTX action in the pathway of NF- $\kappa \mathrm{B}-$ mediated trans-activation of HIV-1 LTR. Initially we examined the influence of PTX on protein kinase-catalyzed cytoplasmic activation of NF- $\kappa$ B and its interaction with the motifs, the two events (steps 2 and 5) of this multistep NF- $\kappa \mathrm{B}-$ mediated trans-activation process. In a cell-free system, PKC and PKA catalyze activation of NF- $\kappa$ B. We characterized two specific inhibitors (calphostin $\mathrm{C}$ and $\mathrm{H} 88$ ) and a nonspecific inhibitor (H7) and then used them to define the PMA- and TNF- $\alpha$-induced activation pathway of NF- $\kappa$ B in the intact cells as dependent on PKC which is inhibited by PTX and by calphostin $\mathrm{C}$, another PKC-specific inhibitor.

\section{MATERIALS AND METHODS}

\section{Cells}

Jurkat $\mathrm{CD}^{+} \mathrm{T}$ lymphocytes were maintained in RPMI 1640 (GIBCO/BRL, Gaithersburg, MD, U.S.A.) tissue culture medium supplemented with $10 \%$ fetal bovine serum (FBS) at $37^{\circ} \mathrm{C}$ in an atmosphere of $5 \% \mathrm{CO}_{2}$ and $95 \%$ air. $293-27-2$ is a human embryo kidney cell line in which the pNAZ expression plasmid $(38,39)$ carrying the HIV-1 LTR fused to a bacterial lacZ gene was stably integrated into the chromosome. This cell line, obtained from Dr. L. A. Herzenberg of Stanford University, was maintained in complete Dulbecco's modified Eagle's medium (DMEM, GIBCO/BRL) supplemented with $10 \%$ bovine calf serum (BCS) and L-glutamine in $5 \% \mathrm{CO}_{2}$ and $95 \%$ air at $37^{\circ} \mathrm{C}$.

\section{Reagents}

Pentoxifylline (PTX) was a gift from HoechstRoussel Pharmaceuticals, Inc. (Somerville, NJ, U.S.A.). Protein Kinase C (PKC) purified from rat brain was obtained from Promega Biotech (Madison, WI, U.S.A.). This PKC consists of $\alpha, \beta$, and $\gamma$ isoenzymes and is free of other kinases. cAMPdependent protein kinase A (PKA), 8-bromocAMP, dithiothreitol (DTT), phenyl methyl sulfonyl fluoride (PMSF), phosphatidyl serine, 4-B-phorbol-12-B-myristate acetate (PMA), and ATP were from Sigma Chemical Co. (St. Louis, MO, U.S.A.). Tumor necrosis factor- $\alpha$ (TNF- $\alpha$ ) 
was from Endogen Inc. (Boston, MA, U.S.A.). Calphostin $C$ was from Kamiya Biochemical Co. (Thousand Oaks, CA, U.S.A.), and H88 and H7 were from Seikagaku America, Inc. (Rockville, $M D$, U.S.A.). The complementary strands of the oligonucleotide carrying the wild-type NF- $\kappa B$ motif (5'-TCGACAGGGACTTTCCGAGAG- ${ }^{\prime}$ ) and the mutated NF- $\kappa$ B motif (TCGACACTC ACTT...) were custom synthesized in the core facilities of the Dana-Farber Cancer Institute.

\section{Fractionation of Cytoplasmic Extracts}

Jurkat and 293-27-2 cells were grown in their respective tissue culture media under the abovedescribed conditions. Cytoplasmic extracts were prepared according to the method of Dignam et al. (40) and fractionated by $0-40 \%$ saturation with ammonium sulfate as described by Ghosh and Baltimore (16). The ammonium sulfate precipitate containing the NF- $\kappa \mathrm{B}-\mathrm{I} \kappa \mathrm{B}$ complex was dissolved in buffer A (Tris- $\mathrm{HCl}, \mathrm{pH} 7.5,20 \mathrm{mM}$, $\mathrm{KCl} 100 \mathrm{mM}$, EDTA $0.5 \mathrm{mM}$, DTT $1 \mathrm{mM}$, PMSF $0.5 \mathrm{mM}$, and $10 \%$ glycerol) and dialyzed against a large volume of buffer A. A protease inhibitor cocktail (16) was added to the dialyzed samples, and they were stored at $-80^{\circ} \mathrm{C}$. Protein content was determined according to the method described by Bradford (41).

\section{Cell-Free NF- $\kappa$ B Activation System}

Protein kinase C-catalyzed activation of NF- $\kappa$ B was carried out in a reaction mixture of $5 \mu$ l total volume containing 1-2 $\mu \mathrm{g}$ of ammonium sulfateprecipitated cytoplasmic proteins from unstimulated cells, $100 \mathrm{mM} \mathrm{KCl}, 30 \mathrm{mM}$ Tris- $\mathrm{HCl}, \mathrm{pH} 7.5$, $6 \mathrm{mM} \mathrm{MgCl}, 0.5 \mathrm{mM} \mathrm{CaCl}_{2}$, a lipid mix $(10 \mu \mathrm{M}$ PMA, $0.28 \mathrm{mg} / \mathrm{ml}$ of phosphotidyl serine, $0.3 \%$ Triton X-100), and $200 \mu \mathrm{M}$ ATP in the absence or presence of specified amounts of purified PKC. The reaction was carried out at room temperature for $30 \mathrm{~min}$. The cAMP-dependent PKA-catalyzed activation of NF- $\kappa$ B was conducted in a reaction volume of $5 \mu \mathrm{l}$ containing 1-2 $\mu \mathrm{g}$ of ammonium sulfate-precipitated cytoplasmic proteins from unstimulated cells, $25 \mathrm{mM}$ Tris$\mathrm{HCl}, \mathrm{pH} 7.5,1 \mathrm{mM} \mathrm{MgCl} 2,75 \mu \mathrm{M} \mathrm{ATP}$, and $1 \mathrm{mM}$ 8-bromo-cAMP in the absence or presence of purified cAMP-dependent PKA. The reaction was carried out at room temperature for $30 \mathrm{~min}$. The activation reaction mediated by either kinases was analyzed by electrophoretic mobility shift assay (EMSA) using a ${ }^{32} \mathrm{P}$-labeled oligonucleotide carrying the wild-type NF- $\kappa \mathrm{B}$ motif un- der conditions described previously (3). The level of active NF- $\kappa$ B produced in the cell-free reaction mixture was quantitated by densitometric scanning of the specific autoradiographic signals as described previously (3).

\section{Whole Cell Experiments}

To identify the specific kinase that participates in the pathway of PMA- or TNF- $\alpha$-induced activation of NF- $\kappa B$ in whole cells, stable expression of HIV-1 LTR-driven reporter lacZ gene in 293-27-2 and transient expression of chloramphenicol acetyl transferase (CAT) gene in Jurkat cells was determined. Cells were treated with specific inducers and kinase inhibitors as described in the figure legends. In the case of 293-27-2 cells in which HIV-1 LTR-lacZ fusion gene construct was stably integrated, both NF- $\kappa \mathrm{B}$ binding (by EMSA) and its influence on the reporter gene expression (by $\beta$-gal activity) were measured in the nuclear and cytoplasmic extracts of treated cells as previously described (3). Unstimulated or stimulated (with PMA or TNF- $\alpha$ ) Jurkat cells were transiently transfected with pHIV-1 LTRCAT and treated with specific inhibitors (either calphostin $\mathrm{C}$ or $\mathrm{H} 88$ ) under conditions described in the figure legends. CAT activity in cell extracts was determined as described previously (3).

\section{RESULTS}

\section{PKC- and PKA-Dependent Activation of NF- $\kappa$ B in a Cell-Free System}

A cell-free system was described for the activation catalyzed by purified PKC of NF- $\kappa$ B by phosphorylation of $I \kappa B$ in the cytoplasmic inactive NF- $\kappa \mathrm{B}-\mathrm{I} \kappa \mathrm{B}$ complex and release of active NF- $\kappa \mathrm{B}$ $(9,16)$. In this investigation we have established a similar system with a partially purified cytoplasmic NF- $\kappa \mathrm{B}-\mathrm{I} \kappa \mathrm{B}$ complex from unstimulated Jurkat (T lymphoid) or 293-27-2 (human embryo kidney) cells. PKC or cAMP-dependent protein kinase (PKA) was added, to activate NF- $\kappa \mathrm{B}$ as measured by electrophoretic mobility shift assay (EMSA), by its specific retardation of a ${ }^{32} \mathrm{P}-$ labeled oligonucleotide carrying the NF- $\kappa \mathrm{B}$ motif (3). Since our goal is to quantitate the level of released active NF- $\kappa \mathrm{B}$ from the cytoplasmic inactive NF- $\kappa \mathrm{B}-\mathrm{I} \kappa \mathrm{B}$ complex, we reasoned that measurement of free NF- $\kappa$ B binding with its motif to be a more direct assay of the activation step 
A

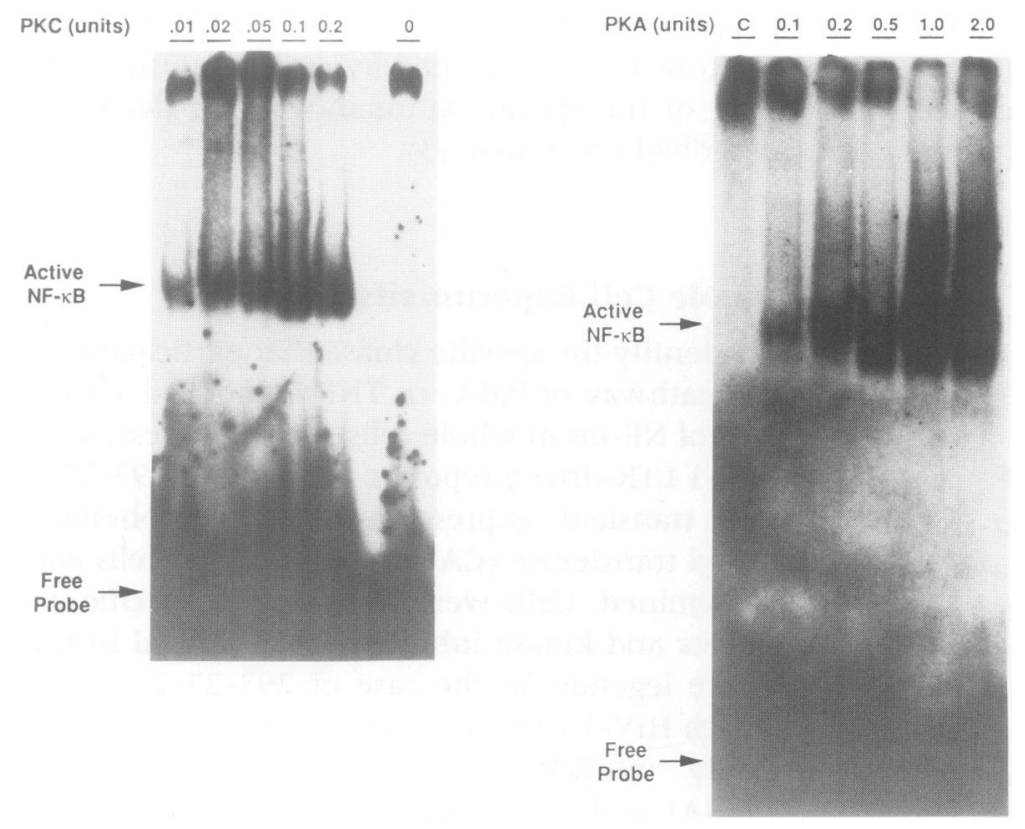

FIG. 1. PKC- and PKA-catalyzed activation of NF- $\kappa$ B with fractionated cytoplasmic proteins of Jurkat cells

The details of the growth of Jurkat cells, isolation, and fractionation of cytoplasm, PKC and PKA reaction conditions, and EMSA are described in Materials and Methods. Two micrograms of ammonium sulfate-precipitated cytoplasmic proteins in the absence $(0$ in $(A)$ and $C$ in $(B))$ or presence of indicated amounts of purified PKC (A) or PKA (B) were used in each reaction. The upper arrows show the interaction of the active NF- $\kappa \mathrm{B}$ and the lower arrows show the free ${ }^{32} \mathrm{P}$-labeled oligonucleotide probe (described in Materials and Methods). than measurement of the phosphorylated $I \kappa B$, the other product of the reaction.

Figure 1 shows a release of active NF- $\kappa \mathrm{B}$ that is dependent upon concentration of added PKC (A) or PKA (B). In the absence of the added enzymes the level of active NF- $\kappa \mathrm{B}$ in the cytoplasmic extracts of unstimulated cells was undetectable (Fig. 1, lane 0, absence of PKC in Fig. 1A and lane $C$, absence of PKA, in Fig. 1B). These results suggest that activation of NF- $\kappa B$ in this cell-free system is dependent on the externally added purified PKC or PKA and the cytoplasmic extract is devoid of such enzyme activity. The characteristic nonspecific interaction of the ${ }^{32} \mathrm{P}$ oligonucleotide commonly observed in similar analyses with crude nuclear extracts ( 3 ) was absent in the EMSA patterns of the cell-free NF- $\kappa$ B activation system with fractionated cytoplasm, as previously reported $(9,16)$. The PKC/PKA-catalyzed cell-free activation of NF- $\kappa \mathrm{B}$ was dependent on ATP and phosphatidylserine for PKC and cAMP for PKA (data not shown).

The specificity of the binding activity was established by competition experiments with wild-type and mutant NF- $\kappa$ B motifs (Fig. 2). The wild-type NF- $\kappa \mathrm{B}$ oligonucleotide competed with ${ }^{32} \mathrm{P}$-labeled oligonucleotide for interaction with active NF- $\kappa \mathrm{B}$, whereas the mutated oligonucleotide, even at 100 -fold higher concentrations, did not compete for binding.

\section{Effects of PTX on Activation of NF- $\kappa B$ by PKC or PKA in a Cell-Free System}

The specific interaction of active NF- $\kappa \mathrm{B}$ with its motif was quantitated by densitometric scanning of the radioactive signal (indicated by an arrow in Fig. 1) as described in Materials and Methods. Figure 3 shows activation of NF- $\kappa$ B by PKA (A) and PKC (B) in cell-free system with extracts from Jurkat (upper panels) and 293-27-2 (lower panels). Previous results from this laboratory demonstrated that PTX treatment of intact Jurkat and human embryo kidney (293-27-2) cells inhibits NF- $\kappa$ B action $(3,42)$. PKC activity is about 5- to 10-fold higher than PKA in this cell-free system and this is more evident with the extract from 293-27-2 cells (Figs. 3A and 3B). The difference in the PKC and PKA activity in the Jurkat cell-free system is in agreement with Ghosh and Baltimore (16) who observed faster kinetics of PKC activity relative to PKA in a similar NF- $\kappa$ B activation system.

To identify sites of this inhibitory action of PTX in the multistep activation pathway, we initially utilized the PKC/PKA-catalyzed cell-free NF- $\kappa$ B activation system. A concentration-dependent inhibition by PTX of activation of NF- $\kappa$ B catalyzed by externally added purified PKC and PKA (Fig. 3C) to extracts of unstimulated cells was observed $\left(\mathrm{IC}_{50}, 0.4-0.5 \mathrm{mM}\right)$. Similar patterns of inhibition of PKC/PKA-catalyzed activa- 


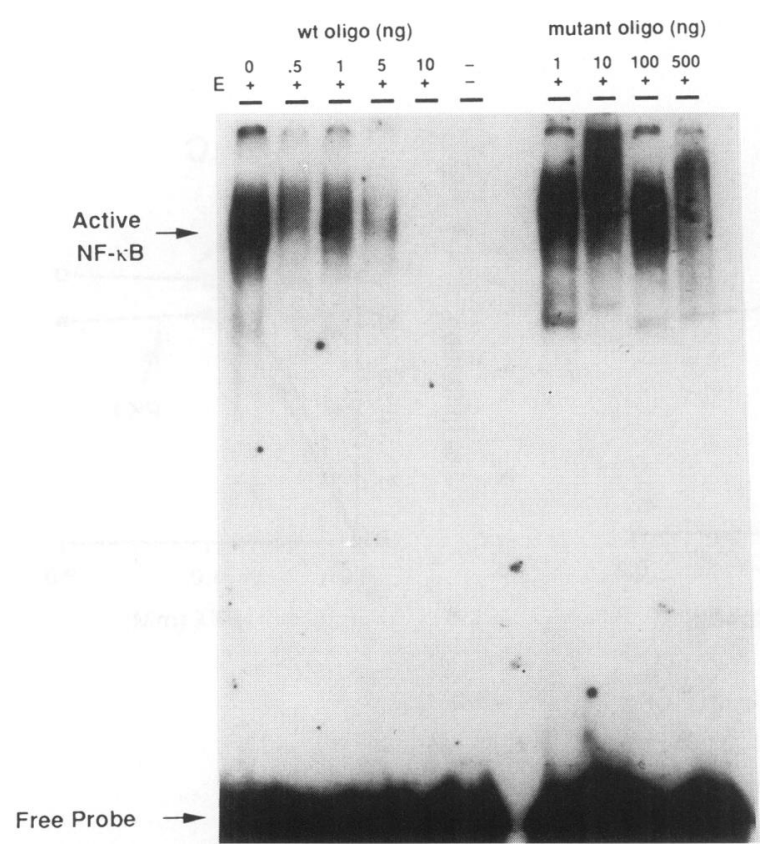

FIG. 2. Specificity of the DNA-protein interaction involving a ${ }^{32} \mathrm{P}$-labeled oligonucleotide containing NF- $\kappa$ B motif and active NF- $\kappa B$ in a cell-free system

The specificity of the interaction of active NF- $\kappa B$ with ${ }^{32} \mathrm{P}$-oligonucleotide in the PKC- or PKA-catalyzed cell-free activation system was determined by competition experiments with nonradioactive oligonucleotides carrying the wild-type (A) or mutated (B) NF- $\kappa$ B motif (described in Materials and Methods). The cell-free NF- $\kappa$ B activation system was as described in Fig. 1 with $1 \mu \mathrm{g}$ of fractionated cytoplasmic protein, $20,000 \mathrm{cpm}$ of ${ }^{32} \mathrm{P}$-labeled oligonucleotide, $0.2 \mathrm{U}$ of PKC (designated by E) plus the indicated amounts ( $\mathrm{ng} / 5 \mu \mathrm{l}$ reaction mixture) of nonradioactive wild-type or mutant oligonucleotides.

tion of NF- $\kappa \mathrm{B}$ were observed with extracts from both Jurkat (Fig. 3, upper panels) and 293-27-2 (Fig. 3, lower panels) cells (Fig. 3C). This kinase inhibition by PTX is consistent with blocking of PKC/PKA activity by other established specific kinase inhibitors.

Another possibility is that PTX directly influences the binding of NF- $\kappa$ B (preactivated in whole cells by PMA) with its motif. We therefore prepared nuclear extracts from PMA-treated cells, which contain activated NF- $\kappa \mathrm{B}$, and determined the influence of PTX on the DNA-protein interaction in cell-free system. Figure 4 shows that PTX added to the cell-free binding reaction did not influence the binding of active NF- $\kappa$ B, whereas, as shown previously, PTX treatment of whole cells inhibited NF- $\kappa$ B interaction with its motifs in both Jurkat and 293-27-2 cells $(3,42)$.
These two sets of data, in addition to the previously reported results with whole cells $(2,3,42)$ suggest that at least one primary site for inhibition by PTX of HIV-1 LTR-mediated gene activation and virus replication is on the protein kinase-dependent activation of NF- $\kappa$ B.

\section{Effects of Other Kinase Inhibitors upon NF- $\kappa$ B Activation}

PTX inhibited both PKC- and PKA-catalyzed activation of NF- $\kappa$ B in the cell-free system. But these results do not specify which of the two kinases inhibited by PTX is involved in the PMAor TNF- $\alpha$-mediated activation in whole cells. Therefore, properties of some established relatively specific protein kinase inhibitors were first tested for their effects in the cell-free NF- $\kappa \mathrm{B}$ activation system. They were then used to characterize specific kinase involvement in activation of $\mathrm{NF}-\kappa \mathrm{B}$ in whole cells.

Calphostin $C$ is reported to be a specific inhibitor of protein kinase $C(32,33)$. We examined this property of the drug in the PKC-catalyzed cell-free NF- $\kappa$ B activation system described previously. Figure $5 \mathrm{~A}$ demonstrates a concentration-dependent calphostin $\mathrm{C}$ inhibition. The $\mathrm{IC}_{50}$ calculated from our experiments is about 0.5 $\mu \mathrm{M}$, which is somewhat higher than the reported value for the drug in another assay system $(0.1 \mu \mathrm{M})$. Most strikingly, the PKA-catalyzed activation of NF- $\kappa$ B was not affected by calphostin $C$ even at 20 -fold higher concentrations, thereby establishing the specificity of action of this drug in this system (Fig. 5A). These concentrations of calphostin $C$ under the specified treatment conditions did not show cytotoxic effects on the cells and were used in whole cell experiments as described below.

H88 is reported to be a specific inhibitor of cAMP-dependent protein kinase A (PKA) (37). This differential inhibitory property of the drug was examined on the PKC- and PKA-catalyzed $\mathrm{NF}-\kappa \mathrm{B}$ activation in the cell-free system. Figure 5B demonstrates a concentration-dependent inhibition by $\mathrm{H} 88$ of PKA-catalyzed release of active NF- $\kappa \mathrm{B}\left(\mathrm{IC}_{50}\right.$ about $\left.0.1 \mu \mathrm{M}\right)$. No significant inhibition of PKC-catalyzed activation of NF- $\kappa$ B by $\mathrm{H} 88$ at more than 500 -fold higher concentrations was detected, demonstrating that $\mathrm{H} 88$ is a specific inhibitor of PKA-catalyzed NF- $\kappa \mathrm{B}$ activation in this system (Fig. 5B).

$\mathrm{H} 7$ has an overlapping inhibition of both the protein kinases. The $\mathrm{IC}_{50}$ 's of the compound for 


\section{Jurkat}

A

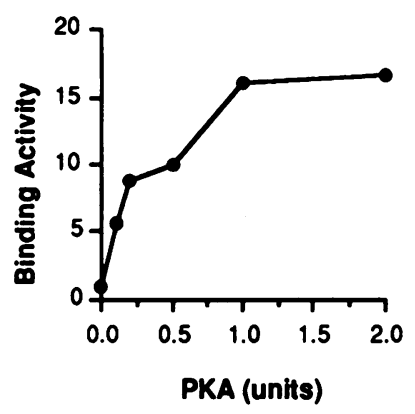

293.27.2

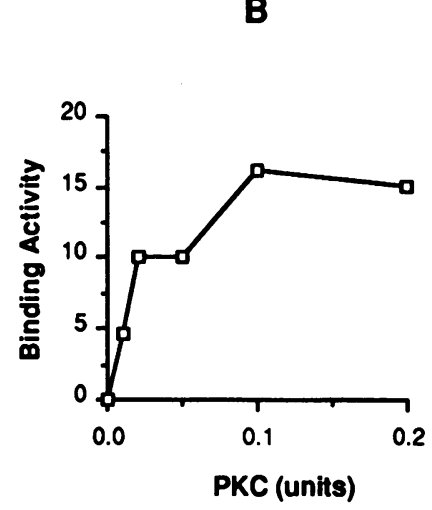

B

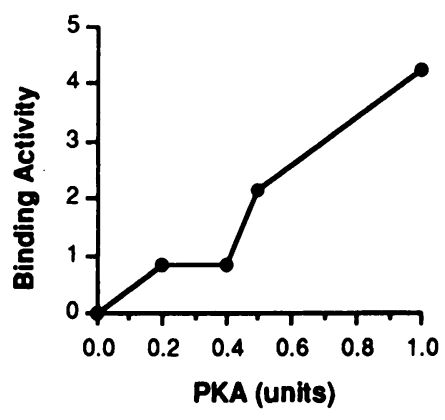

B

A

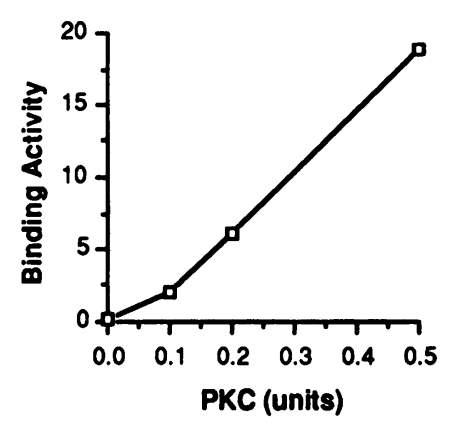

C

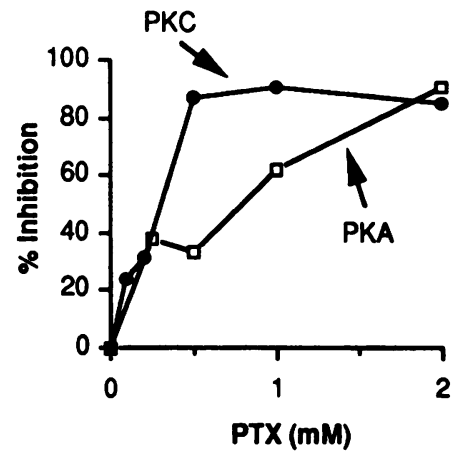

FIG. 3. Inhibition of the binding activity of activated NF- $\mathrm{KB}$ by PTX with cytoplasmic extracts from Jurkat and 293-27-2 cells

Conditions for the PKC- and PKA-catalyzed activation of NF- $\kappa B$ in a cell-free system were as described in the legend to Fig. 1. Two micrograms of fractionated cytoplasmic protein from Jurkat (upper panels) and 293-27-2 cells (lower panels) was used in the presence of indicated units of purified PKA (A) or purified PKC (B) per $5 \mu$ l of reaction mixture. (C) show percent inhibition of PKC $(0.2 \mathrm{U} / 5 \mu \mathrm{l}$ reaction of mixture)- or PKA (2 U/5 $\mu$ l reaction mixture)-catalyzed production of active NF- $\mathrm{KB}$ in a cell-free system in the presence of increasing concentrations of PTX. The level of active NF- $\mathrm{BB}$ in the presence of increasing concentrations of pure enzyme was quantitated by densitometric scanning and integration of the specific autoradiographic signal on an LKB 2222-020 Ultroscan XL Laser Densitometer (LKB Instruments, Houston, TX, U.S.A.). Binding activity (numerals on the y axis) represents the relative intensities of the specific DNA-protein interaction with the ${ }^{32} \mathrm{P}$-oligonucleotide-containing NF- $\kappa \mathrm{B}$ motif (described in Materials and Methods) and the trans-activator.

PKC and PKA have been reported to be 6 and 3 $\mu \mathrm{M}$, respectively $(43,44)$. In the cell-free $\mathrm{NF}-\kappa \mathrm{B}$ activation system, $\mathrm{H} 7$ inhibited both PKC and PKA, although it showed a preferentially greater inhibitory influence on PKC (Fig. 5C). A lowlevel inhibition of PKA with $\mathrm{H7}$ was consistently observed in five independent experiments, but the results were variable. A typical result is presented in Fig. 5C. The IC ${ }_{50}$ of $\mathrm{H7}$ for PKA or its specificity for PKA or PKC could not be conclusively determined from the results of these experiments. 


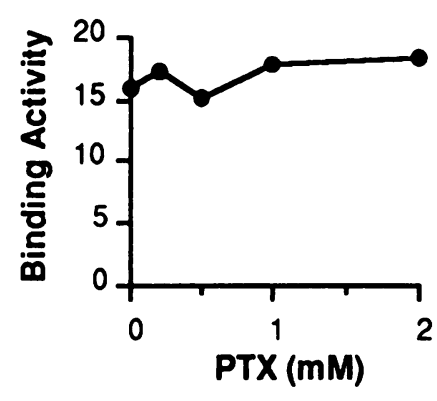

FIG. 4. PTX does not inhibit preactivated (in whole cells) NF- $\mathrm{BB}$ binding with its motif

Jurkat cells were grown under the standard tissue culture conditions in the presence of PMA $(20 \mathrm{ng} /$ $\mathrm{ml}, 12 \mathrm{hr}$ ). Nuclear extracts were prepared and EMSA was conducted with $10 \mu \mathrm{g}$ of nuclear proteins and $20,000 \mathrm{cpm}$ of ${ }^{32} \mathrm{P}$-labeled oligonucleotide carrying the NF- $\kappa \mathrm{B}$ motif, under conditions previously described (3). The figure shows the binding activity in nuclear extracts of PMA-treated cells in the presence of the indicated concentrations of PTX added to the cell-free binding reaction. As previously reported from this laboratory $(3,42)$, nuclear extract isolated from cells treated with PMA and PTX at these same concentrations showed inhibition of NF- $\kappa$ B binding with its motif. The binding activity was determined by densitometric scanning and integration of the specific autoradiographic signal as described above.

\section{TNF- $\alpha$ - and PMA-Induced NF- $\kappa B$ Activation Pathway in Whole Cells}

The pathway of TNF- $\alpha$ - and PMA-induced activation of NF- $\kappa$ B was studied by examining the level of reporter CAT gene activity in cells transiently transfected with pHIV-1 LTR-CAT. The role of PKC and PKA in the activation process was established by treating the cells with either PKC-specific inhibitor, calphostin C, or with the PKA inhibitor H88. Results presented in Fig. 6 demonstrated a calphostin C-dependent inhibition of CAT gene expression in both PMA (A and C) and TNF- $\alpha$ (D and F) treated cells. Treatment with H88 did not show any effect on the level of expression of the reporter gene either in PMA (Figs. 6B and 6E) or in TNF- $\alpha$ (Figs. 6E and $6 \mathrm{~F})$-treated cells. Figures $6 \mathrm{C}$ and $6 \mathrm{~F}$ show average percent inhibition of CAT activity quantitated by densitometric scanning of the signals of duplicate analysis of two other similar experiments with extracts of calphostin $\mathrm{C}$ - and H88treated cells. These results suggest that both TNF- $\alpha$ and PMA-induced activation of NF- $\kappa$ B is catalyzed predominantly by PKC and not PKA in Jurkat cells. The observed inhibition of NF- $\kappa B$ action by PTX in this cell type is thus at least partly due to its inhibitory influence on PKC activity.

Active NF- $\kappa \mathrm{B}$ in the nuclear extracts of PMA- or TNF- $\alpha$-treated $293-27-2$ is elevated as
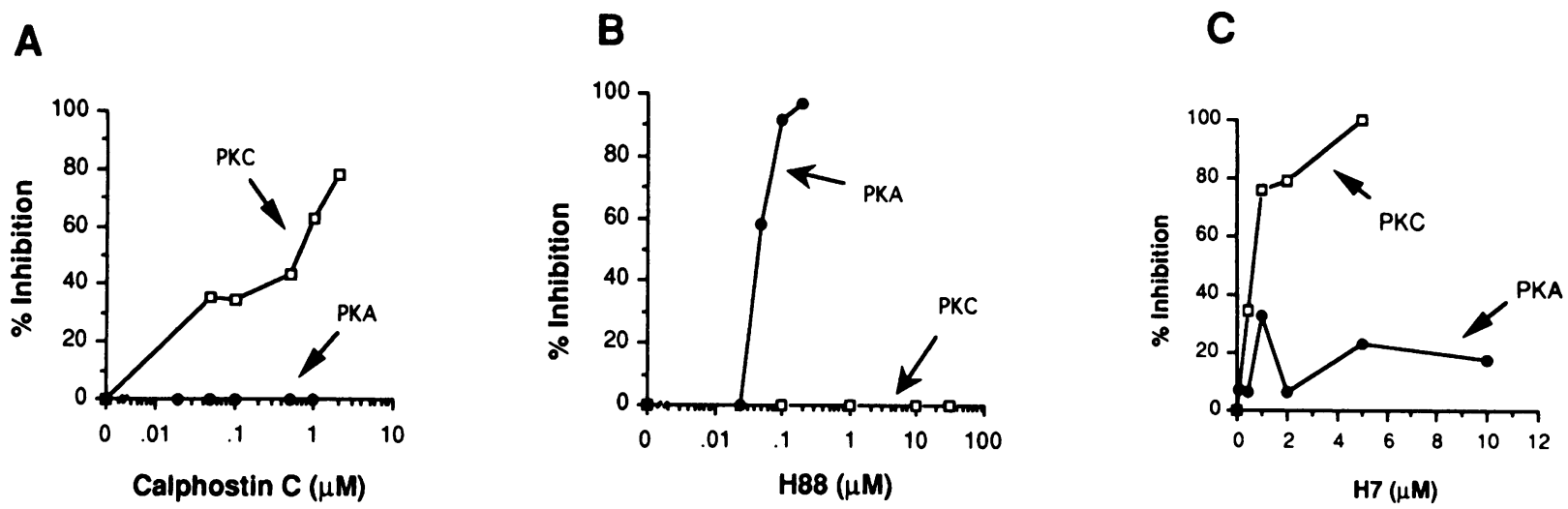

FIG. 5. Influence of calphostin $\mathrm{C}, \mathrm{H88}$, and $\mathrm{H7}$ on the PKC- or PKA-catalyzed activation of NF- $\kappa \mathrm{B}$ in a cell-free system

The results of the cell-free NF- $\kappa \mathrm{B}$ activation system with $2 \mu \mathrm{g}$ of cytoplasmic extract from Jurkat cells in the presence of either $0.2 \mathrm{U}$ of purified PKC or 2 units purified PKA (as in Figs 1-3) are shown. The levels of active NF- $\kappa \mathrm{B}$ produced in the cell-free system in the presence of different concentrations of calphostin C (A), H88 (B), or H7 (C) were determined by quantitation of active NF- $\kappa$ B-specific autoradiographic signals. Percent inhibition of the PKCor PKA-catalyzed release of active NF- $\kappa$ B was calculated from the level of active NF- $\kappa$ B produced in the absence of any drug, which was taken as $0 \%$ inhibition. Typical results of three experiments conducted with all three drugs and two enzymes is presented. 


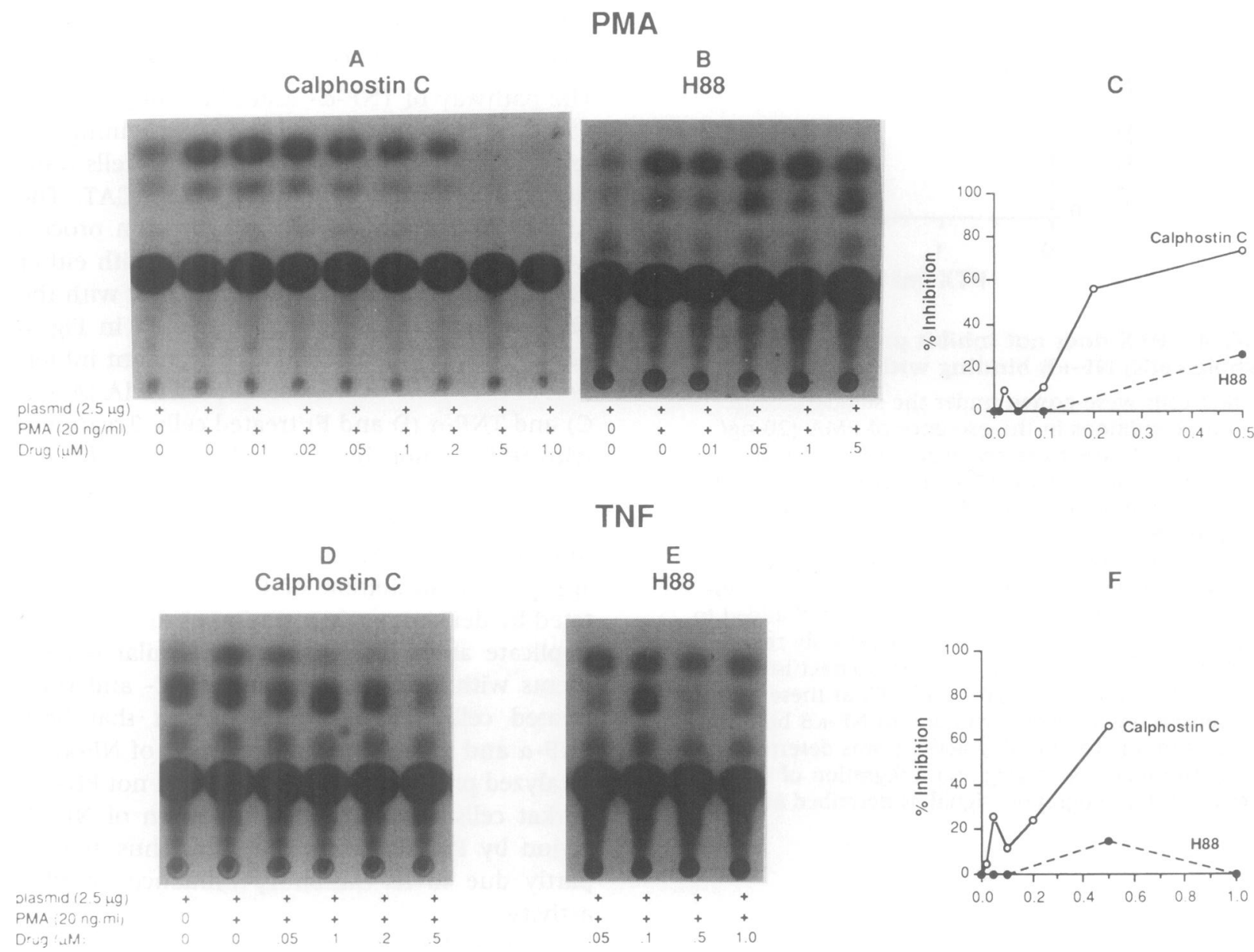

FIG. 6 Influence of calphostin C and H88 on HIV-I LTR-driven reporter gene expression in PMA or TNF- $\alpha$-treated Jurkat cells

Jurkat cells were grown in RPMI-1640 medium supplemented with 10\% fetal bovine serum under standard tissue culture conditions described above. The cells were transfected with $2.5 \mu \mathrm{g}$ of pHIV-1 LTR-CAT (12) by the DEAEdextran procedure (47). Sixty-eight hours after transfection the cells were treated with calphostin C (A and D, under light) or $\mathrm{H} 88$ ( $\mathrm{B}$ and $\mathrm{E}$ ) at the indicated concentrations and incubated in $\mathrm{CO}_{2}(5 \%)$ incubator at $37^{\circ} \mathrm{C}$ for $.5 \mathrm{hr}$. Cells were then treated with PMA $(20 \mathrm{ng} / \mathrm{ml}$; A, B, and C) or TNF- $\alpha(10 \mathrm{ng} / \mathrm{ml} ; \mathrm{D}, \mathrm{E}$, and F) and incubated for an additional $3.5 \mathrm{hr}$ at $37^{\circ} \mathrm{C}$ in $\mathrm{CO}_{2}(5 \%)$ incubator. The cells were then harvested, extracts were prepared, and CAT activity in $10 \mu \mathrm{g}$ (protein) of cell extracts was determined as described previously (3). The (C) and (F) show percent inhibition of CAT activity at the indicated concentrations of the drugs in PMA-stimulated (C) or TNF- $\alpha(\mathrm{F})-$ stimulated cells. The quantitation of CAT activity was made by densitometric scanning of the autoradiographic signals. CAT activity is expressed as percentage ${ }^{14} \mathrm{C}$-chloramphenicol (CAP) derivatives produced per hour in the presence of $10 \mu \mathrm{g}$ of protein in the cell extract. CAT activity in the absence of the drug is considered as $0 \%$ inhibition.

determined from the increased binding of the factor with its motif (3). A simultaneous elevation of HIV-1 LTR-driven reporter gene product, $\beta$-galactosidase activity, in the same PMA- or TNF- $\alpha$-treated cells was also detected. PTX inhibited these increased activities. Since PTX inhibited both PKC- and PKA-catalyzed activation of $\mathrm{NF}-\kappa \mathrm{B}$ in the cell-free system it remains unclear which kinase in whole cells is inhibited. The kinase involved was further identified by treating intact 293-27-2 with an activator in the presence of the inhibitors of PKC or PKA whose specificity had been characterized in the cell-free NF- $\kappa \mathrm{B}$ activation system.

The advantage of studying the influence of specific PKC inhibitor in 293-27-2 cells is the integrated fusion gene construct pHIV-LTR-lacZ which allowed us to monitor simultaneously both NF- $\kappa$ B interaction with its motifs and LTRdriven stably expressed reporter gene activity in 


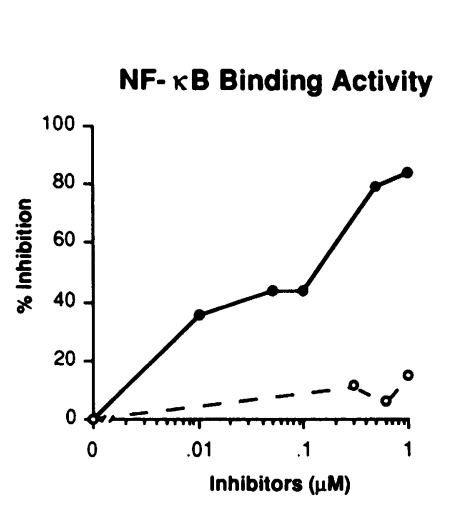

\section{PMA}
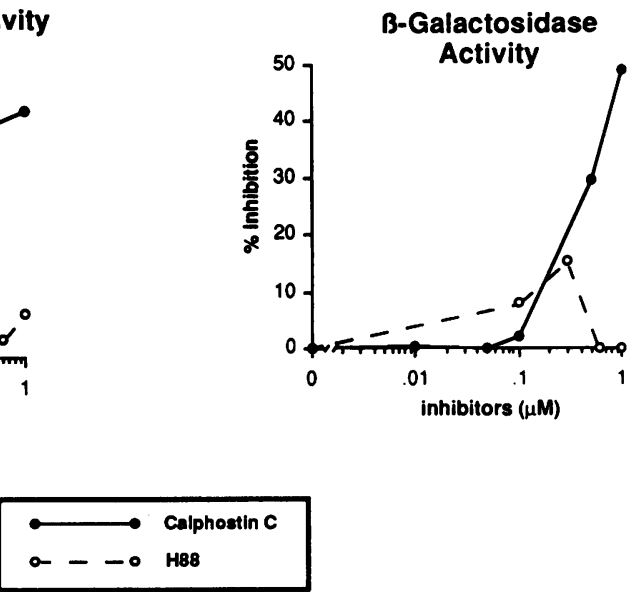

TNF

\begin{abstract}
NF- $\kappa$ B Binding Activity
\end{abstract}

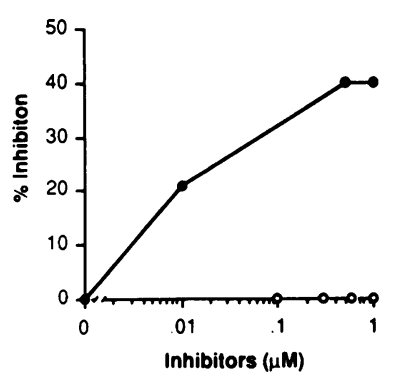

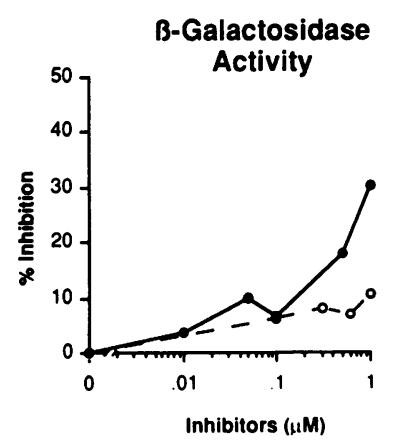

FIG. 7. Influence of calphostin $C$ and $H 88$ on NF- $\kappa$ B binding and HIV-1 LTR-driven reporter gene expression in PMA- and TNF- $\alpha$-treated 293-27-2 cells

293-27-2 cells were grown to semiconfluency under standard tissue culture conditions. Cells were incubated in the presence of calphostin C (under light) or $\mathrm{H} 88$ at the indicated concentrations for $30 \mathrm{~min}$. This was followed by treatment of the cells with PMA $(20 \mathrm{ng} / \mathrm{ml})$ or TNF- $\alpha(10 \mathrm{ng} / \mathrm{ml})$ at $37^{\circ} \mathrm{C}$ for an additional $3.5 \mathrm{hr}$ in $5 \% \mathrm{CO}_{2}$ and $95 \%$ air. An equivalent volume of DMSO was added to control plates (untreated cells). The cells were harvested and cytoplasmic and nuclear extracts were prepared as described previously (3). NF- $\kappa \mathrm{B}$ binding activity in $5 \mu \mathrm{g}$ of nuclear extract were determined by EMSA and $\beta$-galactosidase activity in $10 \mu \mathrm{g}$ of cytoplasmic extract of control and treated cells were determined as described previously (3). Binding activity of NF- $\kappa$ B was determined by densitometric scanning and integration of the specific autoradiographic signal as described in Fig. 3. Percent inhibition was calculated by considering NF- $\kappa \mathrm{B}$ binding and $\beta$-galactosidase activity in the absence of drug as $0 \%$ inhibition. the extracts of same PMA (Fig. 7, upper panels)or TNF- $\alpha$ (Fig. 7, lower panels)-treated cells. Calphostin $C$ inhibited the induced level of interaction of active NF- $\kappa B$ with its motif and simultaneously down regulated HIV-LTR-driven reporter gene expression (Fig. 7). The inhibition of PMA-induced activation and down regulation of reporter gene activity by calphostin $C$ was greater $(80 \%)$ than that of TNF- $\alpha(40 \%)$. As calphostin $C$ has been characterized as a specific inhibitor of PKC (Fig. 5A), these results suggest that both PMA- and TNF- $\alpha$-induced activation of NF- $\kappa$ B in 293-27-2 cells was at least in part catalyzed by PKC. These results are similar to the ones observed in transiently transfected Jurkat cells (Fig. 6). We have observed similar patterns of activation and inhibition of the two reporter gene activities, i.e., CAT in transiently transfected Jurkat cells and lacZ in stably expressed 293-27-2 cells, suggesting that the different reporter genes did not influence gene expression driven by the same HIV-1 LTR sequence.
The possibility that a PKA-catalyzed pathway is also involved in the activation with either PMA or TNF- $\alpha$ of NF- $\kappa$ B in whole cells was examined both in 293-27-2 and Jurkat cells by using the specific PKA inhibitor H88 (as shown in Fig. 5B). In 293-27-2 cells NF- $\kappa$ B interaction with its motifs and HIV-1 LTR-driven reporter gene expression were measured in PMA (Fig. 7, upper panels)- and TNF- $\alpha$ (Fig. 7, lower panels)-stimulated cells. $\mathrm{H} 88$ did not significantly influence either of these parameters of NF- $\kappa \mathrm{B}$ action in these cells. The low level of H88-mediated inhibition observed was not concentration-dependent. Similarly, as shown in Fig. 6, H88 did not influence HIV-1 LTR-driven CAT activity in PMA- or TNF- $\alpha$-stimulated Jurkat cells transiently transfected with pHIV-1 LTR-CAT plasmid. These results substantiate the conclusion of the experiments with calphostin $C$, that the PMA- or TNF- $\alpha$-mediated activation of NF- $\kappa B$ was catalyzed primarily by PKC in both the cell types used in this investigation. 
Similar to results found with $\mathrm{H} 7$ in the cellfree system, in whole cells this compound exhibited inconsistent and low-level inhibition of both kinases at overlapping inhibitory concentrations (data not shown). Therefore, H7 was not useful in further elucidating the pathway of PMA or TNF- $\alpha$ stimulation in whole cells.

\section{DISCUSSION}

PTX, a widely used drug for the treatment of peripheral blood disorders in humans, inhibits HIV-1 LTR activation and viral replication by blocking the trans-activation by NF- $\kappa \mathrm{B}$ (3). In these previous experiments with whole cells, the exact site of action of the drug in the multistep NF- $\kappa \mathrm{B}$ trans-activation process was not identified. To elucidate this question, several steps of the NF- $\kappa \mathrm{B}$ trans-activation process were analyzed by a combination of experiments conducted with a cell-free system and in whole cells. The cellfree system allowed us to identify one site of action of PTX as the kinase-mediated activation of NF- $\kappa$ B. These results, however, do not rule out the possibility that PTX may inhibit additional events in the multistep pathway of NF- $\kappa \mathrm{B}-\mathrm{me}$ diated activation of HIV-l LTR. Recognizing that any cell-free system is subject to uncertainties of altered conditions in extracts versus in vivo, we studied the specific event of protein kinase mediated NF- $\kappa \mathrm{B}$ activation both in cell-free system and in whole cells and obtained consistent results in both of these working systems.

The kinases involved in activation of NF- $\kappa$ B in whole cells have been studied by other investigators using less specific inhibitors at overlapping inhibitory concentrations (see Introduction). Our results suggest that $\mathrm{H} 7$ preferentially inhibited PKC over PKA in a cell-free system and in whole cells. But on the basis of these experiments the activation pathway of NF- $\kappa$ B by PKC versus PKA could not be conclusively established. Results obtained with this inhibitor suffer in general from low specificity and potential inhibition of yet other kinases of which there are a very large number.

The conclusions reached here were obtained by using two relatively specific protein kinase inhibitors, calphostin $\mathrm{C}$ and H88, which showed stringent specificity on one or the other kinase as shown by their inhibitions in extracts of the NF$\kappa \mathrm{B}-\mathrm{I} \kappa \mathrm{B}$ complex as substrate. The specificity of inhibitory action of calphostin $\mathrm{C}$ observed in a cell-free system, the drug's inhibition of both
NF- $\kappa \mathrm{B}$ binding to its motif, and HIV-1 promoter function in whole cells suggest that the critical step of the physiological activation by TNF- $\alpha$ is a PKC-catalyzed release of active NF- $\kappa$ B. This conclusion is further corroborated by results with the PKA-specific inhibitor H88, which did not influence PMA- or TNF- $\alpha$-induced activation of NF- $\kappa \mathrm{B}$ and HIV-1 LTR-driven gene expression, suggesting that PKA does not play a major role in this process, at least in the two cell types used in this investigation. H88, however specifically inhibited PKA in a cell-free system, showing that the compound is active. That a low, concentration-independent inhibition of reporter gene activity was detected (Fig. 7), and that $\mathrm{H} 88$ at higher concentrations was cytotoxic (data not shown) suggest that $\mathrm{H} 88$ was taken up by these cells. Inhibition of the activation of NF- $\kappa \mathrm{B}$ mediated via a kinase other than PKC such as Raf- 1 in whole cells, is not eliminated. However, the pattern of inhibition of PKC by PTX is similar to that observed with a structurally dissimilar compound, calphostin $C$, which is a specific inhibitor of this enzyme, thereby validating this conclusion that the inhibitory influence of PTX is on PKC in whole cells. Recent results of Ratner and Bandres (45) on the suppressive action of the viral protein nef in $\mathrm{T}$ cells, which is also mediated by down regulation of NF- $\kappa$ B action via a PKCdependent mechanism, further substantiate the role of PKC in NF- $\kappa$ B activation and regulation of viral gene expression.

PTX is unlikely to prevent dissociation of phosphorylated $\mathrm{I} \kappa \mathrm{B}$ from NF- $\kappa \mathrm{B}$ because specificity of such a mechanism would not be expected to show the similar results observed with structurally different kinase inhibitors. Inhibition of NF- $\kappa \mathrm{B}$ transport into the nucleus is possible but is not involved in the cell-free system. PTX was shown not to interfere directly with the binding of active NF- $\kappa$ B to its motif.

As expected, PMA-induced activation of NF- $\kappa \mathrm{B}$ is catalyzed by PKC. The novel aspect of these results is the role of PKC in the physiologically more relevant activation by TNF- $\alpha$. PTX can inhibit PKC-catalyzed activation of NF- $\kappa$ B, and thus may in part provide a mechanism for the previously reported anti-NF- $\kappa \mathrm{B}$ and antiHIV- 1 action of PTX $(2,3)$.

We have consistently observed a lack of strict correlation between effects on NF- $\kappa$ B interaction with its motif versus HIV-1 promoter-driven reporter gene expression (3). The inhibitory influence of PKC-specific calphostin C on NF- $\kappa$ B interaction with its motifs was about $80 \%$, as 
compared with an inhibition of HIV-1 promoter function of only $30-50 \%$ (Fig. 7). A noninhibitable basal level of NF- $\kappa$ B in PMA- or TNF- $\alpha-$ treated cells might limit maximal inhibition. This is further corroborated by our observation that the basal NF- $\kappa$ B binding activity and HIV-1 LTRdriven reporter gene activity in unstimulated cells could not be completely eliminated by either of these PKC inhibitors. An alternative possibility is that an HIV-1 promoter activation pathway independent of NF- $\kappa \mathrm{B}$ might be involved. However, mutations in the NF- $\kappa$ B motifs eliminated most of the HIV-l promoter activity, suggesting that NF- $\kappa \mathrm{B}$-mediated activation of HIV-1 LTR is the major pathway in these cells (3).

The PKC inhibitors may also act on virus replication at other sites and activations of other trans-activators. Possible additional interventions of PTX at steps upstream of NF- $\kappa$ B activation by kinases was not eliminated. Diaz-Meco et al. (46) reported the involvement of a dominant negative protein kinase $C$ subspecies in the activation of NF- $\kappa$ B. The mechanism of the inhibitory action of PTX on PKC and the role of different subspecies of this enzyme was not addressed in this investigation.

The results of this study support the potential of kinase $\mathrm{C}$ inhibitors as anti-HIV-l drugs. The synthetic compound Gö 6976, a specific inhibitor of PKC, inhibits HIV-1 induction with little cell toxicity and without the development of resistance (35). PTX and calphostin C as well as this compound could down regulate HIV-1 gene expression and viral replication with little toxicity to cells. PKC-mediated phosphorylation of many cellular key compounds plays a major role in signal transduction. Thus inhibition of such an important cellular function will be deleterious to the cells. However, they might be used in lower noncytotoxic concentrations in combination with other agents such as Tat (trans-activator of transcription) inhibitors, in light of our recent observation on the cooperative action of the Tatinhibitor Ro24-7429 and the NF- $\kappa$ B inhibitor PTX to down-regulate viral gene expression (42).

\section{ACKNOWLEDGMENTS}

The authors thank Dr. L. A. Herzenberg of Standard University for providing the 293-27-2 cells. This research was supported by grants from Hoechst-Roussel Pharmaceuticals Inc., Somerville, NJ, U.S.A., and by a Center for AIDS Research Award to the Dana-Farber Cancer In- stitute. B.J.D. is a Clinical Oncology Career Development awardee of the American Cancer Society.

\section{REFERENCES}

1. Vaishnav YN, Wong-Staal F. (1991) The biochemistry of AIDS. Ann. Rev. Biochem. 60: 577-630.

2. Fazely F, Dezube BJ, Allen-Ryan J, Pardee AB, Ruprecht RM. (1991) Pentoxifylline (trental) decreases the replication of the human immunodeficiency virus type 1 in $\mathrm{Hu}$ man blood mononuclear cells and in cultured cells. Blood 77: 1653-1656.

3. Biswas DK, Dezube BJ, Ahlers CM, Pardee AB. (1993) Pentoxifylline inhibits HIV-1 LTR-driven gene expression by blocking NF- $\kappa \mathrm{B}$ action. J. Acq. Immun. Def. Synd. 6: 778-786.

4. Duh EJ, Maury WJ, Folks TM, Fauci AS, Rabson AB. (1989). Tumor necrosis factor $\alpha$ activates human immunodeficiency virus type 1 through induction of nuclear factor binding to the NF- $\kappa \mathrm{B}$ sites in the long terminal repeat. Proc. Natl. Acad. Sci. U.S.A. 86: 5974-5978.

5 Osborn L, Kunkel S, Nabel GJ. (1989) Tumor necrosis factor $\alpha$ and interleukin-l stimulate the human immunodeficiency virus enhancer by activation of the nuclear factor NF- $\kappa$ B. Proc. Natl. Acad. Sci. U.S.A. 86: 23362340.

6. Sen R, Baltimore D. (1986) Inducibility of $\kappa$ immunoglobulin enhancer-binding protein NF- $\kappa$ B by a posttranscriptional mechanism. Cell 47: 921-928.

7. Baeuerle PA, Baltimore D. (1988) Activation of DNA-binding activity in an apparently cytoplasmic precursor of the NF- $\kappa$ B transcription factor. Cell 53: 211-217.

8. Baeuerle PA, Baltimore D. (1988a) I $\kappa$ B: A specific inhibitor of the NF- $\kappa$ B transcription factor. Science 242: 540-546.

9. Shirakawa F, Mizel SB. (1989) In vitro activation and nuclear translocation of NF- $\kappa B$ catalyzed by cyclic AMP-dependent protein kinase and protein kinase C. Mol. Cell. Biol. 9: 2424-2430.

10. Visvanathan KV, Goodburn S. (1989) Double-stranded RNA activates binding of NF- $\kappa \mathrm{B}$ to an inducer element in the human $\beta$-interferon promoter. $E M B O$ J. 8: 1129-1 138 .

11. Cross SL, Feinberg MB, Wolf JB, Holbrook 
NJ, Wong-Staal F, Leonard WJ. (1987) Regulation of the human interleukin-2 receptor a chain promoter: Activation of a non-functional promoter by the trans-activator gene. Cell 49: 47-56.

12. Nabel GJ, and Baltimore D. (1987) An inducible transcription factor activates expression of human immunodeficiency virus in $\mathrm{T}$ cells. Nature 326: 711-713.

13. Nabel GJ, Rice SA, Knipe DM, and Baltimore D. (1988) Alternative mechanisms for activation of human immunodeficiency virus enhancer in T cells. Science 239: 1299-1302.

14. Chiao PJ, Miyamoto S, Verma IM. (1994) Autoregulation of I kappa B alpha activity. Proc. Natl. Acad. Sci. U.S.A. 91: 28-32.

15. Grilli M, Chiu JJ-S, Lenardo MJ. (1993). NF- $\kappa$ B and Rel-participants in a multiform transcriptional regulatory system. Int. Rev. Cytol. 143: 1-62.

16. Ghosh S, Baltimore D. (1990) Activation in vitro of NF- $\kappa$ B by phosphorylation of its Inhibitor I $\kappa$ B. Nature 344: 678-682.

17. Schutze S, Scheurich P, Schluter C. (1988) Tumor necrosis factor-induced changes of gene expression in U937: Differentiation-dependent plasticity of the responsive state. $J$. Immunol. 140: 3000-3005.

18. Jakobovits A, Rosenthal A, Capon DJ. (1990) Trans-activation of HIV-1 LTR-directed gene expression by tat requires protein kinase C. EMBO J. 9: 1165-1170.

19. Nishizuka Y. (1984) The role of protein kinase $C$ in cell surface signal transduction and tumor promotion. Nature 308: 693-698

20. Meichle A, Schütze S, Hensel G, Brunsing D, Krönke M. (1990) Protein kinase C-independent activation of nuclear factor $\kappa \mathrm{B}$ by tumor necrosis factor. J. Biol. Chem. 265: 8339-8343.

21. Hohmann H-P, Remy R, Scheidereit C, vanLoon APG. (1991) Maintenance of NF- $\kappa B$ activity is dependent on protein synthesis and the continuous presence of external stimuli. Mol. Cell. Biol. 11: 259-266

22. Shirakawa F, Cedid M, Suttles J, Pollok BA, Mizel SB. (1989) Interleukin 1 and cyclic AMP induce $\kappa$ immunoglobulin light-chain expression via activation of an NF- $\kappa \mathrm{B}-$ like protein. Mol. Cell. Biol. 9: 959-964.

23. Li S, Sedivy JM. (1993) Raf-1 protein kinase activities the NF- $\kappa \mathrm{B}$ transcription factor by dissociating the cytoplasmic NF- $\kappa \mathrm{B}-\mathrm{I} \kappa \mathrm{B}$ complex. Proc. Natl. Acad. Sci. U.S.A. 90: 9247-9251.
24. Hidaka H, Inagaki M, Kawamoto S, Sasaki Y. (1984) Isoquinolinesulfonamides, novel and potent inhibitors of cyclic nucleotide dependent protein kinase C. Biochemistry 23: 50365041.

25. Krishnamurthi S, Joseph S. (1989) Arachidonate release in neutrophils: Does a lack of effect of protein kinase $C$ inhibitors imply no involvement of protein kinase C? Biochem. J. 261: 687-688.

26. Sha'afi RI. (1989) Some effects of phorbol esters are not mediated by protein kinase $C$. Biochem. J. 261: 688-690.

27. Hidaka H, Hagiwara M. (1987) Pharmacology of the isoquinoline sulfonamide protein kinase $C$ inhibitors. TIPS 8: $162-164$.

28. Kinter AL, Poli G, Maury W, Folks TM, Fauci AS. (1990) Direct and cytokine-mediated activation of protein kinase $\mathrm{C}$ induces human immunodeficiency virus expression in chronically infected promonocytic cells. $J$. Virol. 64: 4306-4312.

29. Hagiwara $M$, Inagaki $M$, Hidaka H. (1987) Specific binding of a novel compound, $\mathrm{N}-[2-$ (methylamino) ethyl]-5 isoquinolone sulfoneamide (H8) to the active site of cAMPdependent protein kinase. Mol. Pharmacol. 31: 523-528.

30. Kischel T, Harbers M, Stabel S, Borowski P, Muller K, Hilz H. (1989) Tumor promotion and depletion of protein kinase $C$ in epidermal JB6 cells. Biochem. Biophys. Res. Commun. 165: 981-987.

31. Quick J, Ware JA, Driedger PE. (1992) The structure and biological activities of the widely used protein kinase inhibitor, H7, differ depending on the commercial source. Biochem. Biophys. Res. Commun. 187: 657663.

32. Kobayashi E, Nakano H, Morimoto M, Tamaoki T. (1989) Calphostin C (UCN1028C): A novel micribial compound, is a highly potent and specific inhibitor of protein kinase C. Biochem. Biophys. Res. Commun. 159: 548-553.

33. Iida $T$, Kobayashi E, Yoshida $M$, Sano $H$. (1989) Calphostins, novel and specific inhibitors of protein kinase C. II. Chemical structures. J. Antibio. 42: 1475-1481.

34. Bruns RF, Miller FD, Merriman RL, Howbert JJ, Heath WF, Kobayashi E, Takahashi I, Tamaoki T, Nakano H. (1991) Inhibition of protein kinase $C$ by calphostin $C$ is light dependent. Biochem. Biophys. Res. Commun. 176: 288-293. 
35. Qatsha KA, Rudolph C, Marme D, Schachtele C, May WS. (1993) Gö 6976, a selective inhibitor of protein kinase $C$, is a potent antagonist of human immunodeficiency virus 1 induction from latent/low-level-producing reservoir cells in vitro. Proc. Natl. Acad. Sci. U.S.A. 90: 4674-4678.

36. Herbert JM, Augereau JM, Maffrand J. (1990) Chelerythrine is apotent and specific inhibitor of of protein kinase C. Biochem. Biophys. Res. Commun. 172: 993-999.

37. Chijiwa N, Mishima A, Hagiwara M, Sano $M$, Hayashi $K$, Inoue $T$, Hidaka H. (1990) Inhibition of forskolin-induced neurite outgrowth and protein phosphorylation by a newly synthesized selective inhibitor of cyclic-dependent protein kinase $(\mathrm{N}-[2-(\mathrm{p}-$ bromo cinnamylamino) ethyl]-5-isoquonoline). J. Biol. Chem. 265: 5267-5272.

38. Roederer M, Staal FJT, Raju PA, Ela SW, Herzenberg LA, Herzenberg LA (1990) Cytokine-stimulated human immunodeficiency virus replication is inhibited by $\mathrm{N}$ acetyl-L-Cysteine. Proc. Natl. Acad. Sci. U.S.A. 87: 4884-4888.

39. Staal FJT, Roederer $M$, Herzenberg LA, Herzenberg LA. (1990) Intracellular thiols regulate activation of nuclear factor $\kappa \mathrm{B}$ and transcription of human immunodeficienc virus. Proc. Natl. Acad. Sci. U.S.A. 87: 9943-9947.

40. Dignam JD, Lebovitz RM, Roeder RD. (1983) Accurate transcription initiation by RNA polymerase II in a soluble extract from isolated mammalian nuclei. $\mathrm{Nucl}$. Acids Res. 11: 1475-1489.

41. Bradford MM. (1976) A rapid sensitive method for the quantitation of microgram quantities of protein utilizing the principle of protein dye binding. Annal. Biochem. 72: 248-254.

42. Biswas DK, Ahlers CM, Dezube BJ, Pardee AB. (1993a). Cooperative inhibition of NF$\kappa B$ and Tat-induced superactivation of human immunodeficiency virus type 1 long terminal repeat. Proc. Natl. Acad. Sci. U.S.A. 90: 11044-1 1048.

43. Kawamoto S, Hidaka H. (1984) 1-(5-Isoquinolinesulfonyl)-2-methylpiperazine (H7) is a selective inhibitor of protein kinase $\mathrm{C}$ in rabbit platelets. Biochem. Biophys. Res. Commun. 125: 258-264.

44. Nishikawa $M$, Uemura $Y$, Hidaka $H$, Shirakawa S. (1986) 1-(5-isoquinolinesulfonyl)-2-methylpiperazine (H7), a potent inhibitor of protein kinases, inhibits the differentiation of HL-60 cells induced by phorbol diester. Life Sciences 39: 1101-1 107.

45. Ratner L, Bandress J. (1993). HIV-1 nef suppresses transcription through NF- $\kappa \mathrm{B}$ and APl in T cells through protein kinase C-dependent mechanism. Natl. Conf. Hum. Retrovir. Dec. 12-16, Abstract 638, pp. 171.

46. Diaz-Meco MT, Berra E, Municio MM, Sanz L, Lozano J, Dominguez I Diaz-Golpe V, Lainde-Lera MT, Alcami J, m-Paya CV, Arennzana-Seisdedos A, Virelizier J-L, Moscat J. (1993) A dominant negative protein kinase $\mathrm{C}$ by $\xi$ subspecies blocks NF- $\kappa \mathrm{B}$ activation. Mol. Cell. Biol. 13: 4770-4775.

47. Sompayrac LM, Dana KJ. (1981) Efficient infection of monkey cells with DNA of Simian Virus. Proc. Natl. Acad. Sci. USA 78: 75757578. 